\title{
Sepsis cu pneumococ la un copil cu sindrom nefrotic
}

\author{
Iulia Armean', Lorena Elena Meliț1,2, Carmen Duicu ${ }^{1,2}$ \\ ${ }^{1}$ Clinica Pediatrie I, Spitalul Clinic Judeţean de Urgenţă, Tg. Mureş, România \\ ${ }^{2}$ Universitatea de Medicină şi Farmacie, Tg. Mureş, România
}

\begin{abstract}
REZUMAT
Introducere. Sindromul nefrotic reprezintă una dintre cele mai frecvente patologii glomerulare întâlnită la vârsta pediatrică, având o incidenţă de 4,7 cazuri la 100.000 de copii. Cea mai frecventă complicaţie infecţioasă a sindromului nefrotic este peritonita bacteriană, cauzată de cele mai multe ori de Streptococcus pneumoniae, microorganism responsabil de un număr mare de pneumonii, otite medii şi sepsis în rândul copiilor. Prezentare de caz. Prezentăm cazul unui copil, de sex masculin, în vârstă de 4,7 ani, cunoscut cu sindrom nefrotic cu două recăderi şi hipertensiune arterială tranzitorie, internat în clinica noastră pentru următoarele acuze: durere difuză abdominală, vărsături, diaree, febră, otalgie dreaptă. Analizele de laborator realizate în ziua internării au evidenţiat markeri inflamatori crescuţi, leucocitoză, anemie şi dislipidemie mixtă. Sumarul de urină a evidenţiat proteinurie masivă. Hemocultura a fost pozitivă pentru Streptococcus pneumoniae. Ecografia abdominală a pus în evidenţă ascită în cantitate mică, radiografia toracică a exclus o posibilă pneumonie, iar examenul clinic ORL a evidenţiat membrană timpanică eritematoasă şi bombată. S-a iniţiat terapie empirică cu Ceftriaxonă, corticoterapie şi simptomatice. După 3 săptămâni de spitalizare, pacientul este externat in stare generală bună, cu sindrom nefrotic în remisie.

Concluzii. Otita medie acută congestivă poate reprezenta în cazul pacienţilor imunodeprimaţi un punct de plecare pentru un sepsis sever cu Streptococcus pneumoniae. Astfel, vaccinarea antipneumococică este indispensabilă mai ales în cazul pacienţilor cu risc crescut.
\end{abstract}

Cuvinte cheie: sindrom nefrotic, sepsis, otită medie, Streptococcus pneumoniae

\section{INTRODUCERE}

Sindromul nefrotic (SN) este o patologie frecvent întâlnită în clinicile de nefrologie atât în ţările dezvoltate, cât şi în cele în curs de dezvoltare, reprezentând una dintre cele mai frecvente patologii glomerulare care apare la vârsta pediatrică (1-3). Incidenţa SN la nivel mondial este de 4,7 cazuri la 100.000 de copii, iar prevalenţa este estimată la 16/100.000 de copii cu vârsta sub 16 ani $(2,4)$. Clasic, este definit ca proteinurie masivă $\left(>40 \mathrm{mg} / \mathrm{m}^{2} /\right.$ hr) responsabilă de hipoalbuminemie $(<2,5 \mathrm{~g} / \mathrm{dl})$ şi edeme generalizate. (1,5-9). Majoritatea cazurilor sunt SN sensibile la corticosteroizi, dar cu toate acestea aproximativ $20 \%$ dintre cazuri sunt refractare la corticoterapie, cel mai frecvent datorate glomerulosclerozei focal segmentare. Aceste cazuri sunt caracterizate de progresia rapidă spre insuficienţa renală cronică, necesitând dializă şi transplant renal în primi ani de la diagnostic $(2,4)$. Morfopatologic, SN idiopatic este reprezentat cel mai frecvent de glomerulonefrita cu modificări minime $(80 \%$ dintre cazuri) sau de glomeruloscleroză focal segmentară. Alte tipuri histologice de SN întâlnite în rândul copiilor includ glomerulonefrita membranoproliferativă şi, mai rar, nefropatia membranoasă $(6,4,3)$.

În cadrul SN, de multe ori pot apărea complicaţii severe, datorate în principal pierderilor urinare masive de proteine plasmatice (1). Eliminarea urinară a proteinelor cu greutate moleculară mică cum ar fi: imunoglobulina $\mathrm{G}$, factorul I şi factorul $\mathrm{B}$, pot duce la alterarea opsonizării, fagocitozei şi a întregului 
proces de eliminare a bacteriilor, astfel rezultând imunodeprimarea prezentă la pacienţii cu SN (10).

Complicaţiile SN sunt împărţite în două mari categorii: complicaţii datorate bolii de bază sau complicaţii asociate terapiei. Prima categorie include infecţiile (peritonite, sepsis, celulită şi varicelă), tromboembolism (tromboembolism venos şi embolie pulmonară), hipovolemie (durere abdominală, tahicardie şi hipotensiune), hiperlipemia, insuficienţă renală cronică, anemia etc. (1). Se estimează că aproximativ 1,5\% dintre cazurile de SN la copii ajung pană la deces, ca o consecinţă a infecţiilor supradăugate, asociate patologiei de bază (11). Din această categorie, cea mai frecventă complicaţie este peritonita bacteriană spontană, întâlnită la 1,5 până la 16\% dintre cazuri (10). Majoritatea cazurilor de peritonită sunt cauzate de bacterii gram pozitive încapsulate, în special de Streptococcus pneumoniae, care reprezintă, de asemenea, o cauză majoră de meningită, pneumonie, otită medie acută şi sepsis în rândul copiilor $(10,12,13)$.

Răspunsul inflamator sistemic include cel puţin două dintre următoarele criterii: tahipnee, tahicardie, hipertermie sau hipotermie şi leucocitoză sau leucopenie $(14,15)$.

Sepsisul este definit ca disfuncţie de organ care pune viaţa în pericol, fiind datorată răspunsului inadecvat al organismului gazdă la infecţie, reprezentând una dintre cele mai importante cauze de deces la nivel mondial cu o incidenţă în continuă creştere. Conform Society of Critical Care Medicine şi European Society of Intensive Care Medicine, în 2016, s-a stabilit că disfuncţia de organ poate fi reprezentată printr-un scor SOFA (Sequential Organ Failure Assessment) crescut, acesta fiind asociat cu mortalitate intraspitalicească mai mare de $10 \%$. Scorul SOFA rapid (qSOFA), este mai puţin robust, nu necesită teste de laborator şi poate fi obţinut rapid şi în mod repetat, putând fi utilizat prompt pentru stabilirea disfuncţiei de organ şi pentru a iniţia sau pentru a escalada terapia (16-18).

\section{PREZENTARE DE CAZ}

\section{Motivele internării}

Prezentăm cazul unui copil, de sex masculin, în vârstă de 4,7 ani, internat în clinica noastră pentru următoarele acuze: durere difuză abdominală, vărsături, diaree, febră înaltă, otalgie dreaptă. Din an- tecedentele personale patologice, pacientul este cunoscut cu sindrom nefrotic cu două recăderi şi hipertensiune arterială tranzitorie. Menţionăm că pacientul provine dintr-un mediu precar, este nevaccinat, nevitaminizat, prezentând complianţă extrem de redusă la tratament.

\section{Examen clinic}

La momentul internării, examenul obiectiv a evidenţiat următoarele elemente patologice: stare generală influenţată, tegumente palide, lucioase, edeme generalizate $\mathrm{cu}$ semnul godeului pretibial, otalgie dreaptă, tahicardie 146/min, hipertensiune 115/78 $\mathrm{mmHg}$, tahipnee $30 / \mathrm{min}$, febră înaltă $39,7^{\circ} \mathrm{C}$, abdomen destins, sensibil la palpare, vărsături şi scaune diareice, greutate $17 \mathrm{~kg}$, înălţime $107 \mathrm{~cm}$.

\section{Evaluare diagnostică}

Analizele de laborator din ziua internării au evidenţiat: anemie (hemoglobină de $10,7 \mathrm{~g} / \mathrm{dl}$, hematocrit $31 \%$, volum eritrocitar mediu $77,1 \mathrm{fL}$ ), leucocitoză (leucocite $21.800 / \mu 1$ ), neutrofilie (neutrofile $70,6 \%$ ), trombocite $150.000 / \mathrm{mm}^{3}$; markeri inflamatori crescuţi (PCR 58,8 mg/dl, VSH $87 \mathrm{~mm} / \mathrm{h}$ ); hiponatremie ( $\mathrm{Na} 132,2 \mathrm{mmol} / \mathrm{l}, \mathrm{K} 3,97 \mathrm{mmol} / \mathrm{l})$; hipercolesterolemie (412 mg/dl), în timp ce valorile trigliceridelor au fost în limite normale. De asemenea, parametrii funcţiei hepatice şi renale au fost normali. Sumarul de urină a evidenţiat: leucociturie, hematurie $(50 / \mu 1)$, proteinurie masivă $(500 \mathrm{mg} /$ dl), iar proteinuria semicantitativă a fost $>4.500$ $\mathrm{mg} / 1$. Scorul qSOFA a fost 3 , frecvenţa respiratorie 30/min, stare generală alterată cu scor Glasgow 13, hipertensiune arterială $115 / 78 \mathrm{mmHg}$ (stadiu I în funcţie de sex şi înălţime). S-a efectuat o radiografie toracică excluzându-se o posibilă pneumonie. Hemocultura a fost pozitivă pentru Streptococcus pneumoniae, iar antibiograma a arătat sensibilitate la: Penicilină, Amoxicilină, Cefotaxim, Ceftriaxon, Imipenem, Levofloxacină, Moxifloxacină, Ofloxacină, Eritromicină, Linezolid, Vancomicină, Tetraciclină, Cloramfenicol, Rifampicină şi Trimethoprim/Sulfamethoxazol.

Ecografia abdominală a evidenţiat hepatomegalie, nefromegalie şi o lamă fină de lichid perirenal, ascită în cantitate mică.

S-a efectuat consult chirurgical, care a exclus o posibilă peritonită bacteriană spontană. Examenul 
ORL a arătat membrană timpanică eritematoasă, bombată, stabilind diagnosticul de otită medie acută congestivă dreaptă.

\section{Evaluare terapeutică}

Astfel, în urma examenului clinic, paraclinic şi a calculării scorului qSOFA, am stabilit următoarele diagnostice: sepsis cu Streptococcus pneumoniae cu punct de plecare otic, otită medie acută congestivă dreaptă, sindrom nefrotic - recădere, anemie. S-a iniţiat terapie empirică cu Ceftriaxonă, corticoterapie (metilprednisolon intravenos) şi simptomatice, evoluţia fiind favorabilă. După 3 săptămâni de spitalizare, pacientul a fost externat în stare generală bună, în remisie (dispariţia proteinuriei), cu următoarele recomandări: regim hiposodat, hipoglucidic şi hipolipidic, corticoterapie per oral cu sevraj lent şi terapie adjuvantă cu aspacardin, inhibitor de pompă protonică şi suplimente de Ca+Vitamina D3.

\section{DISCUŢII}

În rândul populaţiei pediatrice, cel mai des întâlnit este SN de cauză idiopatică, fiind diagnosticat la $90 \%$ dintre copiii cu SN cu vârsta cuprinsă între 1 şi 10 ani şi la 50\% dintre copii diagnosticaţi după vârsta de 10 ani. Incidenţa bolii este raportată ca fiind între 2 şi 7/100.000 de copii cu vârsta mai mică de 15 ani, dar prevalenţa este mai crescută din cauza caracterului recurent al acestei patologii (7). Incidenţa variază în funcţie de sex, vârstă, etnie şi mediu de provenienţă, fiind mult mai frecventă în rândul pacienţilor de sex masculin, cu un raport pe sexe de 1:3 băieţi, putând să apară la orice vârstă, dar cel mai frecvent cu debut între 2 şi 7 ani $(8,18)$. Asemănător datelor raportate în literatura de specialitate, cazul prezentat mai sus este un copil de sex masculin, cu debutul SN în jurul vîrstei de 3 ani.

Infecţiile sunt printre principalele complicaţii care ameninţă viaţa pacienţilor cu SN, fiind datorate în special Streptococcus pneumoniae, prima cauză a peritonitei bacteriene şi sepsis la aceşti pacienţi (9). $\mathrm{Cu}$ toate acestea, alte microorganisme cum ar fi: streptococul ß-hemolytic, Haemophilus şi bacteriile Gram negative sunt, de asemenea, frecvent întâlnite (1). Astfel, au fost rapotate cazuri de asocieri infecţioase la pacienţii cu SN, cum ar fi prezenţa simultană a peritonitei, celulitei sau a sepsisului (10). Mai mult, au fost descrise cazuri de sepsis cu
Vibrio cholerae, care în principal cauzează boală diareică, însă din cauza imunodepresiei severe, asociată SN, poate determina boli ce ameninţă viaţa pacienţilor (19).

Otita medie $(\mathrm{OM})$ reprezintă una dintre cele mai frecvente patologii întâlnite la vârsta pediatrică, şi una dintre cele mai întâlnite cauze de prezentare la medicul pediatru şi otorinolaringolog $(20,13)$. Printre complicaţiile acestei patologii, nu se numără de rutină sepsisul, pacientul nostru fiind imunodeprimat din cauza patologiei de fond, astfel prezentând sepsis cu punct de plecare otic.

Copiii diagnosticaţi cu SN ar trebui să fie vaccinaţi conform schemei naţionale şi, în plus, ar trebui să fie vaccinaţi împotriva virusului varicelo-zosterian (3), dar şi a Streptococcus pneumoniae (9). Imunizarea reprezintă o metodă eficientă de prevenţie împotriva infecţiilor pneumococice la copii; cu toate acestea, în cazul celor diagnosticaţi cu SN, vaccinarea este destul de controversată,. Studiile recente arată ca vaccinarea nu e la fel de eficientă ca şi la copiii sănătoşi sau poate induce recidive (9). Majoritatea ghidurilor recomandă imunizarea antipneumococică utilizându-se vaccinul pneumococic conjugat 13-valent, posibil urmat de o doză de vaccin pneumococic polizaharid 23-valent, acesta din urmă putând fi administrat doar după vârsta de 2 ani (9). Pacientul prezentat nu a fost vaccinat conform schemei naţionale, fiind astfel mai susceptibil de a dezvolta infecţii bacteriene. Mai mult, vaccinarea antipneumococică ar fi, de asemenea, foarte importantă în acest caz.

\section{CONCLUZII}

Sepsisul reprezintă o cauză majoră de mortalitate şi morbiditate la nivel mondial, având o incidenţă în continuă creştere. $\mathrm{Cu}$ toate că acesta nu se numără printre complicaţiile frecvente ale otitei medii, prezentăm cazul unui copil, provenit dintr-un mediu precar, care asociază SN cu două recăderi (nefiind compliant la tratament), complicându-se infecţios cu o otită medie acută congestivă, care a reprezentat punctul de plecare al unui sepsis cu Streptococcus pneumoniae. Scorul qSOFA ar trebui să fie utilizat prompt în vederea diagnosticării disfuncţiei de organ şi pentru iniţierea tratamentului. Menţionăm importanţa vaccinării la copii, cu preparatele incluse în schema naţională şi, în cazul celor diagnosticaţi cu $\mathrm{SN}$, şi cu vaccinul antipneumococic. 